\title{
Socialbidragstagande och statusbunden skamkänsla \\ - En prövning av ekonomi - sociala band modellen
}

\section{BENGT STARRIN, MARINA KALANDER BLOMKVIST \& STAFFAN JANSON}

\begin{abstract}
I den här artikeln studeras skam och skamrelaterade känslor bland socialbidragstagare. Det görs i ljuset av den s.k. ekonomi-sociala band modellen som i sig fogar samman två vetenskapliga framställningar om skam. Den ekonomiska sidan beaktar den sida som knyter skam och skamrelaterade känslor tillbl.a. fattigdom. Den sida som handlar om sociala band förbinder skam och skamrelaterade känslor med kvaliteten $i$ de sociala relationerna.
\end{abstract}

\section{Inledning}

Det ligger i sakens natur att människor som söker socialbidrag befinner sig i en svår ekonomisk situation. Socialbidraget syftar ju till att vara en sista utpost efter det att alla andra möjligheter att försörja sig är uttömda.

Bengt Starrin är professor i socialt arbete och verksam vid institutionen för samhällsvetenskap, avd för sociologi vid Karlstads universitet

Marina KalanderBlomkvist är doktorand i folkhälsovetenskap vid Karlstads universitet

Staffan Janson är professor i folkhälsovetenskap vid Karlstads universitet
Trots att den moderna socialhjälpen på många punkter är ett framsteg jämfört med den gamla fattighjälpen är det en hel del som talar för att det finns en rad olägenheter av social karaktär som är förbundna med att vara socialbidragstagare. En av dessa rör allmänhetens attityder. Den forskning som belyst allmänhetens uppfattning om dem som är socialbidragstagare tyder på att en betydande del av allmänheten har en negativ inställning till bidragstagare och bidragstagande (Golding \& Middleton, 1982; Halleröd, 1993; Svallfors, 1996). Uppfattningar som att bidragstagande 
beror på lättja och bristande ambition är inte ovanliga.

Socialbidragstagare känner av de attityder som finns om socialbidragstagande. Studier visar att det är vanligt förkommande att man som socialbidragstagare tror att allmänheten anser att socialbidragstagare är lata, utnyttjar systemet, saknar framåtanda, inte kan sköta sin ekonomi, har alkohol eller drogproblem (Jönsson \& Starrin, 1998; Starrin \& KalanderBlomqvist, 2001). I en studie från USA framgår att drygt $2 / 3$ av de intervjuade rapporterade specifika upplevelser om att de behandlats på ett annat sätt av omgivningen när det blev känt att de mottog bistånd. Det handlade om allt från påtaglig antagonism till mer subtila former av ogillande (Rank, 1994).

I John Mayer och Noel Timms klassiska studie "The Client Speaks" framgår att många upplevde att det var förödmjukande att leva på socialbidrag (Mayer \& Timms, 1970). Även flera skandinaviska studier visar på att det är vanligt att känslor som förödmjukelse, förnedring och skam är förbundna med bidragstagande (Gunnarsson, 1993; Jönsson \& Starrin, 1999; Nilsson, 1989; Solheim, 1995; Starrin \& Jönsson, 2000; Swärd, 1995).

För många som ansöker om socialbidrag är själva ansökningsförfarandet en kritisk händelse. En nordisk undersökning genomförd av Ilse Julkunen visar att ca 60 procent av de intervjuade klienterna fann det svårt att besöka socialbyrån. Den främsta orsaken hade att göra med skammen att gå dit, att inte kunna försörja sig själv, upplevelser av att behöva tigga, att känna sig som en andra klassens medborgare. Framförallt upplevde klienterna situationen som förödmjukande och nedvärderande (Julkunen, 1992).

Flera studier pekar således i riktning mot att socialbidragstagandet för många är förenat med känslor av obehag och t.o.m. skam. Även om socialbidraget dämpar den ekonomiska stressen något så tycks det rymma en rad olägenheter som handlar om den låga sociala status som bidragstagandet har och som bl.a. yttrar sig i skamrelaterade känslor (t.ex. mindervärde, värdelöshet, förödmjukelse). Syftet med föreliggande studie är att öka kunskapen om detta fält genom att studera variationer i skam och skamrelaterade känslor i ljuset av nekonomi-sociala band» modellen.

\section{Teoretiska utgångspunkter}

I denna studie används en modell som vi benämner ekonomi-sociala band modellen för att undersöka variationerna i de känslor av skam som är förbundna med socialbidragstagande. Den teoretiska referensramen för denna modell tar sin utgångspunkt $\mathrm{i}$ två sidor av sociologiska och socialvetenskapliga framställningar av emotioner i allmänhet och skam i synnerhet. Den första aspekten kan betecknas som socialpsykologisk och interaktionistisk och förknippas med sociologer som Cooley (1922), Goffman (1967), Scheff (1990) och Retzinger (1991). För Cooley (1922) uppstår skam och stolthet när en person ser på sig själv med den andres ögon. Denna process är central i hans socialpsykologi och $\mathrm{i}$ hans tes om spegeljaget. Hans begrepp om spegeljaget, i vilket självets sociala natur ligger, referar direkt och exklusivt till skam 
och stolthet. Skam och stolthet tillhör, enligt Cooley, kategorin självkänslor och enligt honom föreställer vi oss alltid hur den andre personen uppfattar oss. Vi tar till oss den bedömning som den andre gör, värderar den och värderingen resulterar $i$ någon form av självkänsla såsom stolthet eller skam. Vid skam kan det handla om att känna sig avvisad, otillräcklig, mindervärdig och betydelselös. Goffman (1967) är kanske den som mer än någon annan sociolog konkretiserat Cooleys tanke om spegeljaget. Goffman använde sig dock mer sällan av begreppet skam. Istället använde han begreppet förlägenhet. Förlägenhet betraktar vi som en variant av skam som kan hänföras till gruppen finkänslighetsskam. Bland moderna sociologer är det framför allt Scheff (1990) och Retzinger (1991) som utvecklat den mer generella sociologiska teoribildningen om skam. De relaterar dessa känslor till karaktären hos de sociala banden. Skam signalerar otrygga och osäkra sociala band och stolthet trygga och säkra sociala band. Skam och stolthet ger således besked om tillstånden i de sociala relationerna.

Men skam - och även dess motpol stolthet - anses höra till de emotioner som ligger djupast dolda i de moderna samhällena samtidigt som dessa har betecknats som de mest sociala av alla känslor (Scheff, 1990). Skammen är social därför att i skammen riktas den andres omedelbara negativa blickar mot det egna självet. Grunden för skam är att den alltid innefattar självet $i$ relation till andra personer även om det bara sker i föreställningsvärlden. Därför ger skamkänslan i dess varierande former besked om de sociala bandens karaktär och vilken status man har i de grupper man ingår.

Scheff (1990) och Retzinger (1991) betraktar skam som ett familjekluster av emotioner som innefattar många varianter - från vardagliga små pinsamheter och mild förlägenhet till intensiva former som förödmjukelse, förnedring och vanära. Att känna skam, är att känna sig alienerad, omintetgjord, förkrossad, nedvärderad, misslyckad, förlöjligad, värdelös, mindervärdig.

Den andra sidan av de framställningar av skam som är av intresse för denna studie är den koppling som företeelsen har till hierarkiska aspekter av samhället som låg social status (Neckel, 1991; Collins, 1990; Kemper, 1990), låg social klass (Neckel, 1991; Sennett, 1999; Sennett \& Cobb, 1973), maktlöshet (Kaufman, 1993) och social underordning (Lehtinen, 1998, Scheff \& Starrin, 2002; Starrin, 2001). Även om skamkänslan är en ofrånkomlig sida av människans liv sätts här focus på den skam som knyts till att befinna sig i ett tydligt socialt och materiellt underläge. Tankegången är att i moderna samhällen som präglas av individualism, konkurrens och prestationsorientering riskerar misslyckanden att hävda sig i konkurrensen om ekonomiska resurser, social status, social prestige och makt att uppfattas som uttryck för personlig svaghet och underlägsenhet samt något som den enskilde får skämmas för. Detta finns tydligt uttalat hos t.ex. Lehtinen (1998), Neckel (1991), Sennett (1999) och Sennett \& Cobb (1972). Trots all mångfald och heterogenitet som präglar moderna kapitalistiska samhällen tenderar de värdesystem som ligger till grund för 
status, prestige och makt att utformas under stark påverkan av dominerande klassers intressen, vilket innebär att den som inte lyckas att bli framgångsrik kommer att känna sig underlägsen. Öden och sociala omständigheter blir således i den postmoderna individualiserade kulturen till ett personligt ansvar (Neckel, 1991). Därför tenderar förhållanden som fattigdom och arbetslöshet att upplevas som ett personligt nederlag. Detta är ett tema som återfinns hos flera författare. Sennetts ståndpunkt är att misslyckanden är vår tids tabu. Om misslyckanden talar man inte öppet och därför ökar den psykiska fixeringen och skammen. De som är beroende av samhällets välfärdsstöd betraktas, enligt Sennett, med misstänksamhet - som om de vore samhällsparasiter och inte verkligt hjälplösa. Han betraktar ideologin om samhällsparasitism som ett kraftfullt disciplinärt verktyg. Det gör att människor som är beroende av samhällets stöd skäms, vilket för med sig en rad konsekvenser. Exempelvis undergrävs förtroende och engagemang människor emellan. Så långt Sennett.

En sida av den status- och klassbundna skammen är fattigdom. Det finns otaliga framställningar - både historiska och moderna - om fattigskammen. Att vara fattig i moderna välfärdssamhällen ses som ett individuellt misslyckande - som en personlig brist och inte som något som är orsakat av samhälleliga kriser. De fattigas identitet och självkänsla påverkas negativt av inflytande från två håll. Å ena sidan föreställningen och förekomsten av andra människors negativa och kritiska uppfattningar och som inte ger uttryck för någon sympati för de fattiga. $\AA$ andra sidan kan de fattigas uppfattning om sig själva ge upphov till självförakt om de anammar samhällets negativa uppfattningar om fattiga. Och här ligger det som Scheff (1990) benämner skammens dynamik, dvs den dynamiska kraft som ligger i skambeläggande och känslan av skam och som kan bidra till att befästa social underordning och ojämlikhet. Medlemmar i underordnade grupper eller klasser har, menar Scheff, speciella svårigheter med skam på grund av att skammen dels är ett resultat av yttre hån och förakt från omgivningen och dels ett resultat av inre händelser. Personer som åtnjuter låg status och som befinner sig $i$ ett socialt underläge lider inte bara brist på omgivningens aktning. För att kunna klara av vardagen tvingas de också att inta de dominanta gruppernas föraktfulla attityder och således se på sig själva som mindre värda. Detta blir till en kraftfull källa av självgenererad skam. Det finns mycket som talar för att klassherravälde inte bara har sin grund i den härskande klassens förfogande över maktmedel för social kontroll utan också i de lägre sociala klassernas känslor. Passivt accepterande av orättvisa vilar på två komplementära rörelser hos de underordade klasserna. För det första, skam över dess medlemmars egenskaper och för det andra, idealisering av den härskande klassens egenskaper. Det skulle betyda att den sociala differentieringen av klasser i styrande och styrda inte bara vilar på den legitima kontrollen av makt utan också på skammens kollektiva dynamik (Scheff, 1990).

Syftet med denna undersökning är att studera skamkänslan och dess variationer bland socialbidragstagare. Det görs i ljuset 
av ekonomi-sociala band modellen. Vi antar att den skam som är förbunden med socialbidragstagandet påverkas av två förhållanden, nämligen graden av ekonomisk påfrestning och karaktären i de sociala banden dvs om de är trygga eller otrygga (se figur 1). Mer specifikt antar vi att (i) kombinationen "högre grad av ekonomisk påfrestning" och notryggare sociala band" är förenat med omfattande skam- och skamrelaterade känslor (ruta $\mathrm{A}$ ); (ii) kombinationen »lägre grad av ekonomisk påfrestning" och "tryggare sociala band" är förenat med ringa skam- och skamrelaterade känslor (ruta D). Vi antar dessutom att tryggare sociala band mildrar den effekt som högre grad av ekonomisk påfrestning har på utbredningen av skam- och skamrelaterade känslor (ruta B) och att lägre grad av ekonomisk påfrestning mildrar den effekt som otryggare sociala band har på utbredningen av skam- och skamrelaterade känslor (ruta C).

Vi ansluter oss till Scheffs syn på skam som ett familjekluster av emotioner som innefattar flera varianter - från vardagliga små pinsamheter och mild förlägenhet till intensivare former som förödmjukelse, förnedring och vanära.

\section{Undersökningens genomförande}

Föreliggande undersökning använder sig dels av ett kvantitativt empiriskt material och dels - i illustrativt syfte - av ett kvalitativt intervjumaterial.

\section{Den kvantitativa undersökningen}

Föreliggande studie baseras på data från en undersökning som genomfördes under perioden september 1999 - januari 2000. Undersökningspopulationen bestod av 4488 hushåll som någon gång under andra halvåret 1998 och första halvåret 1999 ansökt om socialbidrag $i$ antingen någon av Värmlands 16 kommuner eller i Karlskoga kommun.

I varje kommun gjordes ett slumpmässigt urval av 300 hushåll bland dem som någon gång under den aktuella perioden

\section{Figur $\mathbf{I}$.}

Ekonomi-sociala band modellen och känslan av skam, en hypotetisk modell.

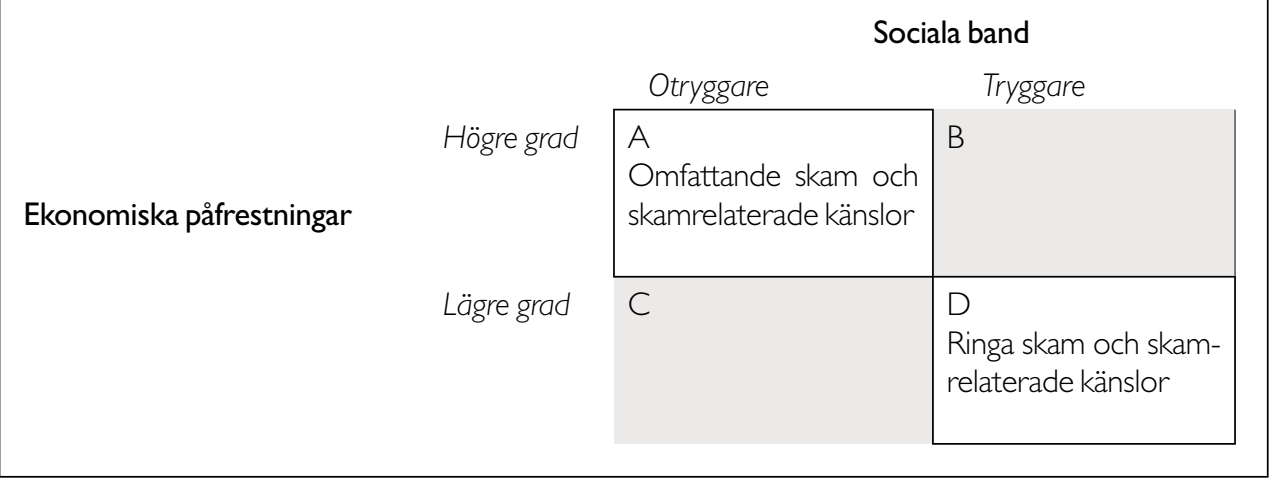


ansökt om socialbidrag. I de fall som antalet bidragssökande understeg 300 hushåll medtogs alla de sökande i populationen. Undersökningen genomfördes med hjälp av en postenkät. ${ }^{1}$ Frågeformulär skickades till den person i hushållet som var registrerad som sökande hos respektive socialtjänst. Totalt skickades två påminnelser ut.

1999 av 4488 hushåll besvarade formuläret. 257 hushåll definierades som externt bortfall (dödsfall, flyttning, sjukdom). Svarsfrekvensen uppgick därmed till 47 procent och bortfallet till 53 procent. Vi har inte haft möjligheter att genomföra analys av bortfallet eftersom uppgifter om bakgrundskarakteristika inte har varit tillgängliga för oss.

\section{Frågor och operationaliseringar}

I figur 2 framgår hur ekonomi-sociala band modellen operationaliserats. Faktorn $e k o-$ nomisk påfrestning består av en sammanvägning av de sju variabler som redovisas i figur 2. Sammanvägningen har genomförts med hjälp av faktoranalys (principal components). Antagandet är att dessa utgör indikatorer på graden av ekonomisk

1 Undersökningsinstrumentet bestod av ett frågeformulär som innehöll frågor om sociala bakgrundsförhållanden som t.ex. kön, ålder, boendeform, utbildning, sysselsättning etnicitet m.m. Formuläret innehöll vidare frågor om sociala kontakter, ekonomiska förhållanden, kontakter med socialkontoret, känsloupplevelser, hälsoförhållanden, förtroende för olika samhälleliga institutioner, känsla av sammanhang (KASAM), framtidstro och självförtroende. påfrestning. Faktorn ekonomisk påfrestning har grupperats på två sätt. (1) Vid tillämpningen av ekonomi-sociala band modellen på frågan om man känt skam och känt sig förnedrad i samband med besök vid socialkontoret, har den ekonomiska faktorn indelats i tre grupper, högre grad av ekonomisk påfrestning, medel grad av ekonomisk påfrestning och lägre grad av ekonomisk påfrestning. (2) Vid tillämpningen av ekonomi-sociala band modellen på frågan om man känt skam, känt sig generad, känt sig förnedrad i samband med att man handlat med rekvisition, indelades den ekonomiska faktorn i två grupper, högre grad av ekonomisk påfrestning och lägre grad av ekonomisk påfrestning. Anledningen till det senare förfarande är att andelen som handlat med rekvisition utgör endast 30 procent av den undersökta gruppen.

Faktorn sociala band består av en sammanvägning av två frågor (se figur 2). Vi antar att frågan om man berättat för någon annan än sina närmaste i familjen att man har eller har haft socialbidrag och frågan om man skulle tycka det vore förargligt om folk t.ex. en granne fick veta att man mottog socialbidrag är indikatorer på om de sociala banden är tryggare eller otryggare. På samma sätt som beskrivits för faktorn ekonomisk påfrestning har faktorn sociala band i ena fallet indelats i tre grupper (tryggare sociala band, måttligt trygga band och otryggare band) och i det andra fallet i två grupper (tryggare resp otryggare sociala band). Sammanvägningen har genomförts med hjälp av faktoranalys (prin cipal component).

Utöver dessa har vi använt oss av ett

Starrin, Kallander Blomkvist \& Janson: Socialbidragstagande och statusbunden skamkänsla ... 
antal frågor om sociala bakgrundsförhållanden såsom kön, ålder, etnicitet, hushållstyp, utbildning och antal år man ansökt om socialbidrag. Variabeln ålder har indelats i fyra grupper, under 25 år, 25-34 år, 35-44 år och 45 år eller äldre. Faktorn etnicitet består av tre grupper, första generationens invandrare, andra generationens invandrare, ingen invandrarbakgrund. Faktorn hushållstyp har indelats i fyra grupper, ensamboende utan barn under 20 år, ensamboende med barn under 20 år, samboende/gift utan barn under 20 år, samboende/gift med barn under 20 år. Utbildningsfaktorn består av fyra grupper, genomgången folkskola eller yrkesskola, genomgången grundskola eller realskola, genomgången gymnasieskola, postgymnasial utbildning inkl högskola. Faktorn antal år man ansökt om socialbidrag har indelats i tre grupper, 1 år, 2-3 år, 4 år eller fler.

Vi har också använt oss av en fråga som handlar om förtroendet för socialsekreteraren/handläggare. Den fråga som ställdes var "Kände Du stort eller litet förtroende för socialsekreteraren/ handläggare när Du senast besökte socialkontoret för att ansöka om socialbidrag?". Svarsalternativen var "mycket stort förtroende", "ganska stort förtroende", "varken stort eller litet förtroende", "ganska litet förtroende», "mycket litet förtroende». Vårt antagande är att förtroende för socialsekreterare/handläggare modifierar sambanden mellan »ekonomi-sociala band modellen" och skam (och skamrelaterade känslor).

\section{Operationalisering av skam och skamrelaterade känslor}

I figur 2 redovisas de frågor som använts för att mäta de skam och skamrelaterade känslor som har att göra med socialbidragstagande. Vi betraktar dessa som statusbundna skamkänslor. En fråga ställdes som rör känslor av skam och förnedring $i$ samband med besök vid socialkontoret för att ansöka om socialbidrag. I föreliggande undersökning utnyttjar vi även frågor om man känt skam, känt sig generad och känt sig förnedrad i samband med att man handlat med rekvisition.

Vi betraktar skam som ett kluster av självkänslor som bl.a. omfattar att känna sig generad och känna sig förnedrad. Av analytiska skäl kommer vi att behandla de tre nämnda känslorna separat.

Vid bearbetningen har svarsalternativen »i ganska hög grad» och »i mycket hög grad» förts samman.

\section{Bearbetning och analys}

Data har bearbetats och analyserats dels med hjälp av s.k. enkel tabellanalys innebärande studier av enskilda samband med utnyttjande av chi2 test och dels med hjälp av logistisk regressionsanalys. I det senare fallet har vi vid analysen av sambandet mellan ekonomi-sociala band modellen och känslor av skam jämfört tre utfall. I modell 1 har den logistiska regressionen genomförts utan justering för sociala bakgrundsförhållanden. I modell 2 sker en justering för sociala bakgrundsförhållanden och i modell 3 sker dessutom en justering för den inverkan som faktorn förtroende för socialassekreterare har. 
Figur 2

Operationalisering av ekonomi-sociala band modellen

\begin{tabular}{|c|c|}
\hline \multicolumn{2}{|c|}{ Ekonomi-sociala band modellen } \\
\hline 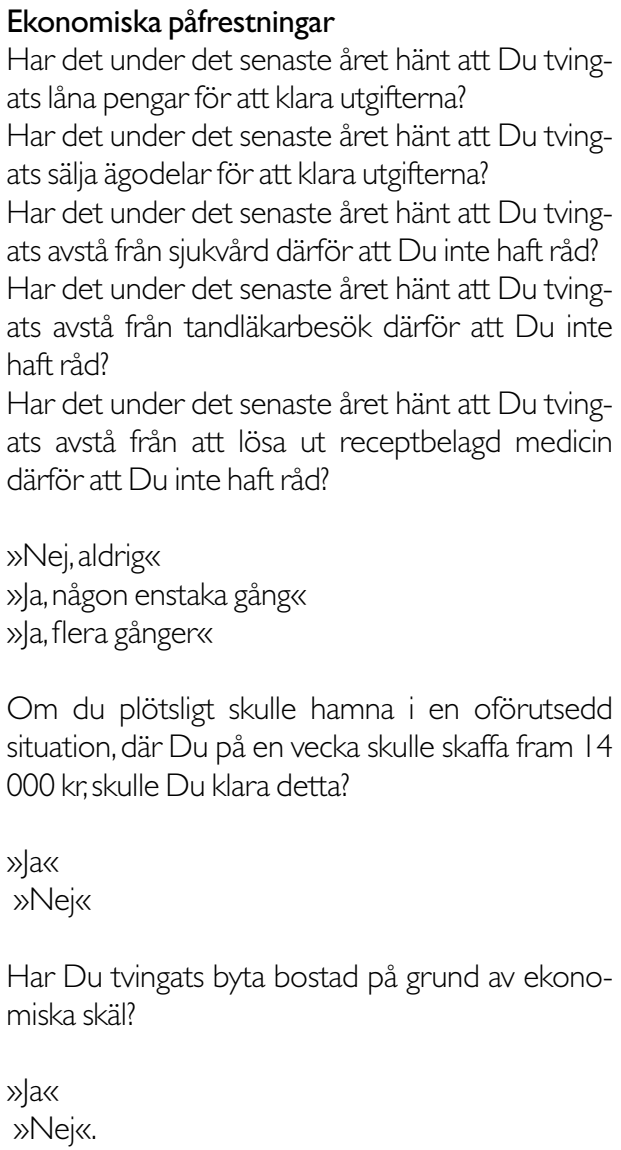 & $\begin{array}{l}\text { Sociala band } \\
\text { Har Du berättat för någon annan än Dina när- } \\
\text { maste i familjen att Du har eller har haft social- } \\
\text { bidrag? } \\
\text { »la« } \\
\text { »Nej« } \\
\text { Om folk t ex en granne fick veta att Du mottog } \\
\text { socialbidrag skulle Du tycka att det var förargligt } \\
\text { eller spelar det inte någon roll? } \\
\text { »Det skulle vara mycket förargligt« } \\
\text { »Det skulle vara lite förargligt« } \\
\text { »Det skulle inte spela någon rollk }\end{array}$ \\
\hline
\end{tabular}

\begin{tabular}{|c|c|}
\hline \multicolumn{2}{|c|}{ Känslor av skam } \\
\hline 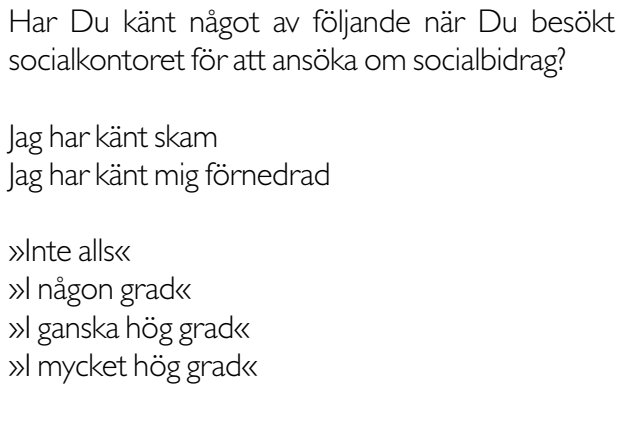 & $\begin{array}{l}\text { I hur hög grad har Du känt följande känslor när } \\
\text { Du handlat med rekvisition? } \\
\text { Jag kände skam } \\
\text { Jag kände mig generad } \\
\text { Jag kände mig förnedrad } \\
\text { »Inte alls« } \\
\text { »I någon grad« } \\
\text { »l ganska hög grad« } \\
\text { »l mycket hög grad« }\end{array}$ \\
\hline
\end{tabular}

Starrin, Kallander Blomkvist \& Janson: Socialbidragstagande och statusbunden skamkänsla ... 


\section{Beskrivning av undersökningsgruppen}

Drygt 60 procent i den undersökta gruppen är kvinnor. Drygt en fjärdedel är under 25 år och ungefär en lika stor andel är över 45 år. Den vanligaste hushållstypen är ensamboende utan barn (39 procent). Drygt var tredje är öppet arbetslös eller i arbetsmarknadsåtgärd. Femton procent har själva invandrat. Ca 45 procent har högst grundskola i sin utbildning. Den vanligaste utbildningsbakgrunden är genomgången gymnasieskola. Värt att notera är att drygt var fjärde invandrare (26 procent) har en utbildning som motsvarar minst ett år utöver gymnasieskolan. Motsvarande siffra bland dem utan invandrarbakgrund är 13 procent.

\section{Personliga intervjuer med socialbidragstagare}

I föreliggande studie används även utdrag ur intervjuer med ett antal socialbidragstagare som rör ekonomiska förhållanden, erfarenheter av att bli behandlad på ett nedlåtande sätt, uppfattningar om allmänhetens attityder till socialbidragstagare samt

2 Personliga intervjuer genomfördes med 35 personer som haft socialbidrag under minst sex månader. Intervjuerna ägde rum under perioden april 1999 till maj 2000. Undersökningsgruppen bestod av 22 kvinnor och 13 män. Sex av de redovisade intervjuerna genomfördes tillsammans med både kvinnan och mannen i hushållet. Åldern på de intervjuade varierade mellan 20 och 79 år. Urvalet av intervjupersoner gick till på följande sätt. Kommunernas socialkontor försåg oss med namn på personer som uppfyllde det kriterium som ställts upp dvs att personen i fråga skall ha upplevelser av att handla med rekvisition. ${ }^{2}$ Vi har valt berättelser vari respondenterna uttrycker någon form av skamkänslor.

I vissa berättelser använder de själva ordet skam för att beskriva sina känslor och i andra berättelser användes omskrivningar av denna känsla. I det senare fallet har vi haft hjälp av Retzingers språkliga markörer för skam för att spåra uttryck för skam- och skamrelaterade känslor (se Retzinger, 1991 sid 69-74). Av utrymmesskäl kan dessa markörer inte förtecknas här.

\section{Resultat}

\section{Ekonomiska förhållanden}

87 procent av undersökningsgruppen har under det senaste året tvingats låna pengar för att klara sina utgifter. Variationerna med avseende på kön och ålder är små.

42 procent har under det senaste året tvingats sälja ägodelar för att klara utgifterna. Skillnaderna mellan könen är relativt stora. För kvinnor är siffran 36 procent och för män 52 procent.

Mer än hälften, 54 procent, har under

haft socialbidrag sammanlagt under minst sex månader. Personerna kontaktades av socialkontoren och tillfrågades om de var villiga att ställa upp för en intervju. Intervjuer har genomförts med stöd av en manual som bestod av ett antal teman som t.ex. ekonomiska förhållanden, uppfattningar om allmänhetens attityder till socialbidragstagare, upplevelser av att handla med rekvisition, andras bemötande, den egna hälsan. Intervjuerna har bandats och skrivits ut. Därefter har utdrag ur intervjuerna grupperats och kategoriserats. 
det senaste året avstått från sjukvård därför att de inte haft råd. Kvinnor har avstått $\mathrm{i}$ något större utsträckning än män (kv 56 \%; män 50\%).

Två tredjedelar eller 66 procent har tvingats avstå från tandläkarbesök under det senaste året (kv 69\%; män 63\%). 46 procent har tvingats avstå från att lösa ut receptbelagd medicin. Skillnaderna mellan könen är betydande (kv 51\%; män 39\%).

87 procent saknar kontantmarginal dvs kan inte, om en oförutsedd händelse skulle uppstå, skaffa fram $14.000 \mathrm{kr}$. Kvinnor saknar kontantmarginal i större utsträckning än män (kv 90\%; män 82\%).

32 procent har tvingats byta bostad av ekonomiska skäl (kv 33\%; män $31 \%$ ).

57 procent grubblar dagligen över ekonomin och detta gäller i lika utsträckning för kvinnor och män.

\section{Socialbidragets sociala dimensioner-skam och skamrelaterade känslor}

77 procent uppger att de har berättat för andra än de närmaste att de har socialbidrag (kv 78\%; män 77\%). 51 procent uppger att det skulle vara förargligt (mycket förargligt eller lite förargligt) om folk t.ex. någon granne fick reda på att man mottog socialbidrag. Det är vanligare att kvinnor upplever det som förargligt än vad männen gör (kv 54\%; män 47\%).

30 procent har erfarenhet av att, i stället för pengar, få rekvisition för att t.ex. kunna handla mat (kv $29 \%$; män 30\%).

När det gäller känsloupplevelser i samband med besök på socialkontoret framgår att 47 procent känt skam och 40 procent känt sig förnedrade. Kvinnor rapporterar i högre grad dessa känslor och skillnaderna mellan kvinnor och män är signifikanta.

Det framgår även av tabell 1 att ålder är signifikant relaterat till känslor av skam och förnedring. De under 25 år rapporterar i mindre utsträckning dessa känslor.

Som framgår av tabell 1 uppger nära sju av 10 att de i ganska eller i mycket hög grad kände skam, kände sig generade och förnedrade när de handlade med rekvisition. Kvinnor uppger i högre grad dessa känslor än vad män gör. Vi kan notera att det inte finns några signifikanta skillnader i rapporteringen av dessa känslor med avseende på ålder.

\section{Några illustrationer}

\section{Socialbidraget}

I intervjuerna med socialbidragstagare framgår att bidragstagandet rymmer sidor som ger känslor av skam. Skammens klassiska uttryck är att man vill dra sig undan, undvika och dölja det som väcker skamkänslan (Scheff \& Starrin, 2002). Så är det för Marie. Hon är drygt 30 år och har två barn. Hon har under många år, av och till, varit beroende av socialbidrag. Hon säger att »det är så smutsigt på något vis att gå till socialen«. Därför håller hon sitt bidragstagande för sig själv. Hon säger vidare. - Det är skamligt, även om det är något man har rätt till så... Det är en skam att ha med soc. att göra.

Vanja är 51 år och ensamstående med tre barn. Hon är arbetslös och sedan tre år helt beroende av socialbidrag för sin försörjning. Vanja undviker i det längsta att

Starrin, Kallander Blomkvist \& Janson: Socialbidragstagande och statusbunden skamkänsla ... 
gå till socialkontoret. Hon vill inte bli sedd av någon hon känner. Britta säger att gamla attityder sitter djupt inne i folksjälen. »Man är en looser när man går och får socialbidrag".

Einar är pensionär sedan flera år och ensamstående. Han är beroende av socialbidrag eftersom hans pension inte når upp till existensminimum. Einar berättar inte för sina bekanta att han har socialbidrag och det händer att han har tagit till en nödlögn då han stött på någon bekant på sin väg in till socialkontoret. - En får ju ljuga lite ibland.

Erika och Olof bor tillsammans med sina fem barn i en villa i en mindre bruksort. Paret är arbetslösa och har sedan tio år tillbaka i perioder varit beroende av socialbidrag. Erika och Olof har den uppfattningen att det är vanligt att folk tror att socialbidragstagare har missbruksproblem och allvarliga problem inom äktenskapet och familjen. Båda berättar hur det känns när kylskåpet är tomt och hur det känns när man kommer till socialförvaltningen med räkningen i handen. De menar att då hjälper det inte att man har betalat skatt i hela sitt liv och vet att bidraget är en rättighet. - Man vill inte tala om att det är så illa som det är, berättar Olof. - Det är den där skammen, tillägger Erika. - Skammen att inte klara sig själv, avslutar Olof.

Lotta och Lars har mer eller mindre levt på socialbidrag de senaste tio åren. Paret

Tabell. I.

Skam och skamrelaterade känslor $i$ samband med besök på socialkontoret för att ansöka om socialbidrag och $i$ samband med att man handlat med rekvisition, fördelat på kön och ålder.

\begin{tabular}{|c|c|c|c|c|c|c|}
\hline & & \multicolumn{2}{|c|}{$\begin{array}{l}\text { Känslor i samband med } \\
\text { besök på socialkontoret }\end{array}$} & \multicolumn{3}{|c|}{$\begin{array}{l}\text { Känslor i samband med att man } \\
\text { handlat med rekvisition }\end{array}$} \\
\hline & & $\begin{array}{c}\begin{array}{c}\text { Känt } \\
\text { skam } \\
n=|79|\end{array} \\
\end{array}$ & $\begin{array}{c}\text { Känt mig } \\
\text { förnedrad } \\
n=1763\end{array}$ & $\begin{array}{l}\text { Kände } \\
\text { skam } \\
\mathrm{n}=581\end{array}$ & $\begin{array}{c}\text { Kände mig } \\
\text { generad } \\
n=532 \\
\%\end{array}$ & $\begin{array}{c}\text { Kände mig } \\
\text { förnedrad } \\
n=549\end{array}$ \\
\hline & & $\%$ & $\%$ & $\%$ & & $\%$ \\
\hline Totalt & & 47 & 40 & 68 & 68 & 68 \\
\hline \multirow[t]{3}{*}{ Kön } & Kvinnor & 50 & 42 & 72 & 74 & 74 \\
\hline & Män & 41 & 37 & 62 & 58 & 58 \\
\hline & & ***** & **⿻丷木 & $*$ & ***** & ****** \\
\hline \multirow[t]{5}{*}{ Ålder } & Under 25 år & 35 & 33 & 69 & 75 & 71 \\
\hline & 25-34 år & 54 & 43 & 67 & 72 & 66 \\
\hline & 35-44 år & 50 & 44 & 67 & 63 & 65 \\
\hline & 45 år eller äldre & 50 & 42 & 71 & 64 & 70 \\
\hline & & $*$ & $*$ & e.s. & e.s. & e.s. \\
\hline
\end{tabular}

$* \mathrm{p}<.05 * * \mathrm{p}<0.01 * * * \mathrm{p}<.001$ 
har två barn, fyra och åtta år. De många åren av ekonomiska bekymmer ledde till att Lotta för tre år sedan drabbades av en djup depression och tvingades att tillbringa en tid på sjukhus. Lotta och Lars har den uppfattningen att man befinner sig "längst ner« när man lever på socialbidrag. - Ja man är längst ner... Man blir klassad som dom som är uteliggare typ. Man är liksom inte värd mer än skiten under skorna. Den blicken får man... Ja att nu kan du sitta där i skiten...

\section{Att handla med rekvisition}

Studier från England indikerar att bidragstagare utvecklar olika strategier för att handskas med omgivningens negativa attityder. Det mest uppenbara är att dölja det faktum att man mottar bidrag. I Mayer och Timms studie »The Client Speaks" berättade flera att de dolde för sina vänner och t.o.m. för sin familj att de gick på bidrag (Mayer \& Timms, 1970). I vissa situationer är det dock svårt att dölja sitt bidragsberoende. Ett mycket tydligt exempel är när man får en rekvisition att handla för. Då träder man in i ett mer eller mindre offentligt sammanhang. I Ranks amerikanska studie framgår att man då väljer olika strategier för att förhindra att bidragsberoendet blir synligt för andra. En del handlar på udda tider och andra går till affärer där användningen av rekvisitioner är ganska vanligt förekommande och därmed också väcker mindre uppmärksamhet (Rank, 1994).

I vår undersökning berättar Alice som är 43 år och ensamstående med två barn, 6 och 15 år om hur det var när hon i en akut ekonomisk kris fick en rekvisition från socialförvaltningen. Det var hennes första möte med socialtjänsten. - Det var en jobbig grej att få rekvisition och det fick jag då. Och jag som handlat på den affären i så många år. Och man är välkänd och så plötsligt står man där med en rekvisition. Det var ingen som talat om för mig att jag var tvungen att handla för femhundra kronor [summan på rekvisitionslappen]. Och där skulle jag stå i kassan. Det fattar du väl sa dom att du måste handla, du kan ju inte få pengar tillbaka.... och då kände jag att det här ska jag aldrig utsätta mig för. För det var människor som jag blivit väl bemött av förut som plötsligt satte upp en attityd som kändes jättejobbigt. Jag vet inte om det är min upplevelse... Men jag tror inte det. Jag tror att de behandlar mig på ett annat sätt plötsligt. Alice berättar vidare om hur en kassörska som ej sett en rekvisition tidigare vid ett tillfälle när hon står i kassan med sin lapp reser sig upp med rekvisitionen i handen och ropar över till kassörskan i kassan bredvid "hur gör man med en sådan här rekvisition?«. - Då ville jag bara sjunka genom golvet och försvinna.

Eskil är 45 år och ensamstående. Sedan fem år tillbaka är han helt beroende av socialbidrag för sin försörjning. När Eskil första gången gick till socialförvaltningen för att be om hjälp hade han inga pengar till mat och i väntan på att pengarna skulle komma fick han ta emot en matrekvisition. För Eskil var det ingen rolig promenad från socialkontoret till affären. - Det är inte muntert på vägen till affären. Jag tänkte och tänkte, att det här är något man måste utsätta sig för det är inte mer med det, man måste ju ha maten det är ju bara så. Men det är inte

Starrin, Kallander Blomkvist \& Janson: Socialbidragstagande och statusbunden skamkänsla ... 
muntert, det är det inte. Det känns ungefär som att, här ska vi trycka ner dig, liksom. Det är ju skillnad om man inte kan sköta sig överhuvudtaget... Det känns som om man skulle vara missbrukare och skulle gå och köpa sprit för pengarna. Den är hemsk den där lappen... Man står med mössan i handen i stort sett. Man har ju liksom inget annat. Och i regel så är det ju så att det har gått så långt så man är desperat.

Per är 24 år och lever ensam. Han berättar om när han första gången gick till affären för att handla med en rekvisition från socialen. - Det var höjden av förnedring, säger han. Per gick till den affär som han alltid brukade gå till. Han berättar att han inte ville gå till kassan och skylta med rekvisitionen från socialen. - Jag gick bakom lagret och sa till chefen att jag skall handla på en sådan här lapp (rekvisitionen). Det kändes fruktansvärt hemskt. Inga problem sa han och hänvisade mig till en person som skulle ta hand om det. Och sedan fick jag gå ut i affären och hämtade en korg och plockade till mig varor. Jag gick tillbaka till lagret och så fick jag gå ut på baksidan.

\section{Prövning av ekonomi-sociala band modellen}

Ekonomi-sociala band modellen postulerar att utbredningen av skam- och skamrelaterade känslor är större ju högre den ekonomiska påfrestningen är och ju otryggare de sociala banden är.

I figur 3a redovisas utbredningen av skam och förnedring i samband med att man besökt socialkontoret för att ansöka om soci-

\section{Figur 3a.}

Ekonomi-sociala band modellen och skam-och skamrelaterade känslor $i$ samband med besök vid socialkontoret för att ansöka om socialbidrag, fördelat på kvinnor och män.

\section{SOCIALA BAND}

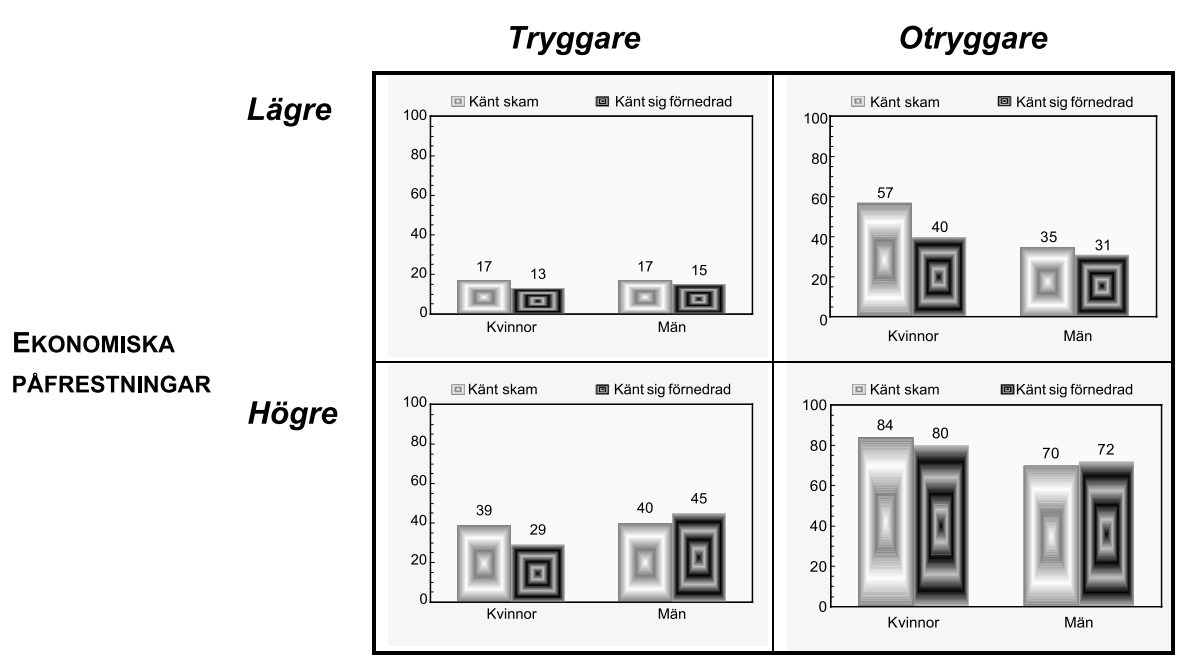


albidrag. I figuren har endast kombinationerna "högre-otryggare», "högre-tryggare», »lägre-otryggare», lägre-tryggare» medtagits. Tydliga skillnader mellan »lägre-tryggare» och »högre-otryggare» kan noteras. Andelen som känt skam i »lägre-tryggare» gruppen är 17 procent för både kvinnor och män. Motsvarande siffra i »högre-otryggare» gruppen är 84 respektive 70 procent. 13 procent av kvinnorna och 15 procent av männen i "lägre-tryggare" gruppen har känt förnedring. Motsvarande siffror i gruppen »högreotryggare« är 80 resepktive 72 procent.

I tabell $2 \mathrm{a}$ och $2 \mathrm{~b}$ redovisas resultatet från en logistisk regressionsanalys i samband med besök på socialkontoret. Vi kan notera att ekonomi-sociala band modellen har en starkare koppling till "skam» än vad den har för "förnedring». Detta gäller både för kvinnor och män.

\section{Tabell 2a.}

Skam och skamrelaterade känslor i samband med besök på socialkontoret

\section{Kvinnor}

\begin{tabular}{|c|c|c|c|c|c|c|}
\hline & \multicolumn{3}{|c|}{ Känt skam } & \multicolumn{3}{|c|}{ Känt mig förnedrad } \\
\hline & Modell I & Modell 2 & Modell 3 & ModellI & Modell 2 & Modell 3 \\
\hline \multicolumn{7}{|l|}{ Ekonomi-sociala band modellen } \\
\hline $\begin{array}{l}\text { Lägre grad av ek. påfrestn. och } \\
\text { tryggare sociala band }\end{array}$ & I & I & I & I & । & । \\
\hline $\begin{array}{l}\text { Lägre grad av ek. påfrestn. och } \\
\text { måttligt trygga sociala band }\end{array}$ & $2.8 * * *$ & $2.6 * *$ & $2.6 * * *$ & I.3 e.s. & 1.3 e.s. & 1.3 e.s. \\
\hline $\begin{array}{l}\text { Lägre grad av ek. påfrestn. och } \\
\text { otryggare sociala band }\end{array}$ & $6.3 * * *$ & $7.2 * * *$ & $7.1 * * *$ & $2.6 * *$ & $2.7 * *$ & $2.6 * *$ \\
\hline $\begin{array}{l}\text { Medel grad av ek. påfrestn. och } \\
\text { tryggare sociala band }\end{array}$ & 1.7 e.s. & 1.7 e.s. & 1.6 e.s. & 1.6 e.s. & 1.6 e.s. & I.4 e.s. \\
\hline $\begin{array}{l}\text { Medel grad av ek. påfrestn. och } \\
\text { måttligt trygga sociala band }\end{array}$ & $5.2 * * *$ & $4.8 * * * *$ & $4.5 * * *$ & $3.8 * * *$ & $3.7 * * * *$ & $3.2 * * *$ \\
\hline $\begin{array}{l}\text { Medel grad av ek. påfrestn. och } \\
\text { otryggare sociala band }\end{array}$ & $11.9 * * *$ & $12.8 * * * *$ & 13.0**** & $5.5 * * *$ & $5.4 * * * *$ & $5.1 * * * *$ \\
\hline $\begin{array}{l}\text { Högre grad av ek. påfrestn. och } \\
\text { tryggare sociala band }\end{array}$ & $3.1 * * *$ & $2.9 * * *$ & $2.4 * *$ & $3.2 * * *$ & $2.8 * * *$ & $2.3 * *$ \\
\hline $\begin{array}{l}\text { Högre grad av ek. påfrestn. och } \\
\text { måttligt trygga sociala band }\end{array}$ & $9.0 * * *$ & 8.4 ***** & $7.1 * * *$ & $8.9 * * *$ & $9.4 * * * *$ & $7.7 * * * *$ \\
\hline $\begin{array}{l}\text { Högre grad av ek. påfrestn. och } \\
\text { otryggare sociala band }\end{array}$ & $26.4 * * * *$ & $25.8 * * * *$ & $24.7 * * *$ & $11.2 * * *$ & 11.4 **** & 10.5 **** \\
\hline
\end{tabular}

Starrin, Kallander Blomkvist \& Janson: Socialbidragstagande och statusbunden skamkänsla ... 
Det finns ett likartat mönster i de tre modellerna för oddskvoterna för "skam" och "förnedring" och som gäller både för kvinnor och män (tabell 2a; tabell 2b). Den relativa risken (uttryckt som oddskvoter) för att känna skam och känna förnedring $i$ samband med besök vid socialkontoret för att ansöka om socialbidrag, ökar i takt med en förändring av de sociala banden från tryggare över måttligt trygga till otryggare, för varje enskild nivå av ekonomisk påfrestning. Vid en ökning av den ekonomiska påfrestningen, givet en viss karaktär hos de sociala banden, ökar dessutom den relativa risken att känna skam och förnedring.

Vad beträffar utfallet av analysen för kvinnor (tabell 2a) finns inga anmärkningsvärda skillnader mellan de tre modellerna för "skam" och "förnedring".

När det gäller män (tabell 2b) kan vi

Tabell 2b.

Skam och skamrelaterade känslor $i$ samband med besök på socialkontoret

Män

\begin{tabular}{|c|c|c|c|c|c|c|}
\hline & \multicolumn{3}{|c|}{ Känt skam } & \multicolumn{3}{|c|}{ Känt mig förnedrad } \\
\hline & Modell I & Modell 2 & Modell 3 & Modell I & Modell 2 & Modell 3 \\
\hline \multicolumn{7}{|l|}{ Ekonomi-sociala band modellen } \\
\hline $\begin{array}{l}\text { Lägre grad av ek. påfrestn. och } \\
\text { tryggare sociala band }\end{array}$ & I & I & I & 1 & 1 & I \\
\hline $\begin{array}{l}\text { Lägre grad av ek. påfrestn. och } \\
\text { måttligt trygga sociala band }\end{array}$ & $5.1 * * * *$ & $5.6 * * *$ & $5.5 * * * *$ & 2.0 e.s. & 2.3 e.s. & I.7 e.s. \\
\hline $\begin{array}{l}\text { Lägre grad av ek. påfrestn. och } \\
\text { otryggare sociala band }\end{array}$ & $4.5 * * * *$ & $3.6 * *$ & $3.5 * *$ & $2.6 * *$ & 2.2 e.s. & 2.2 e.s. \\
\hline $\begin{array}{l}\text { Medel grad av ek. påfrestn. och } \\
\text { tryggare sociala band }\end{array}$ & 1.6 e.s. & I.8 e.s. & I.8 e.s. & 1.6 e.s. & I.4 e.s. & I.0 e.s. \\
\hline $\begin{array}{l}\text { Medel grad av ek. påfrestn. och } \\
\text { måttligt trygga sociala band }\end{array}$ & $4.6 * * *$ & $4.9 * * *$ & $4.6 * * *$ & $2.3 * *$ & I.6 e.s. & 1.0 e.s. \\
\hline $\begin{array}{l}\text { Medel grad av ek. påfrestn. och } \\
\text { otryggare sociala band }\end{array}$ & $16.0 * * * *$ & 20.4 **** & $20.0 * * * *$ & $8.0 * * *$ & $7.6 * * *$ & $7.7 * * *$ \\
\hline $\begin{array}{l}\text { Högre grad av ek. påfrestn. och } \\
\text { tryggare sociala band }\end{array}$ & $2.7 * *$ & $4.1 * *$ & $4.0 * *$ & 4.8 **** & $4.9 * * *$ & $3.7 * *$ \\
\hline $\begin{array}{l}\text { Högre grad av ek. påfrestn. och } \\
\text { måttligt trygga sociala band }\end{array}$ & 14.4 **** & $17.8 * * * *$ & $16.4 * * * *$ & $7.9 * * * *$ & $8.3 * * *$ & $7.2 * * *$ \\
\hline $\begin{array}{l}\text { Högre grad av ek. påfrestn. och } \\
\text { otryggare sociala band }\end{array}$ & $26.0 * * *$ & $32.3 * * * *$ & 31.4 ***** & 14.7 *** & $13.0 * * * *$ & $9.4 * * *$ \\
\hline
\end{tabular}

e.s.ej signifikant $\quad * p<.05$ *** $p<.01 * * * * 0<.001$

Modell I. Utan justering;

Modell 2. Justerat för sociala bakgrundsförhållanden

Modell 3. Justerat för sociala bakgrundsförhållanden och förtroendet för socialsekreteraren. 
notera en tydlig ökning i oddskvoterna för skam i modell 2 jämfört med modell 1 för några av kombinationerna. T.ex. ökar oddskvoten tydligt för gruppen "högreotryggare». När det gäller "förnedring» sker i modell 3 en påtaglig minskning av oddskvoten i gruppen »högre-otryggare« jämfört med modell 2 vilket kan tolkas som så att förtroende för den handläggande socialsekreteraren har en dämpande verkan på känslan av förnedring.

I figur $3 b$ redovisas utbredningen av skam- och skamrelaterade känslor i samband med att man handlat med en rekvisition från socialtjänsten. Som framgår är utbredningen av dessa känslor störst i gruppen "högre-otryggare» dvs bland dem som både är utsatta för en högre grad av ekonomisk påfrestning och vars sociala band är otryggare. Detta gäller såväl för kvinnor som för män. Som framgår är det 25 procent av kvinnorna och 23 procent av männen i »lägre-tryggare» gruppen som känt skam i samband med att de handlat med rekvisition. Motsvarande siffror i gruppen »högre-otryggare» är 88 respektive 84 procent.

I tabellerna 3a och 3b redovisas resultatet från logistisk regressionsanalys av ekonomi-sociala band modellen och skamoch skamrelaterade känslor i samband med att man handlat med en rekvisition från socialtjänsten. Ekonomi-sociala band modellen har prövats i tre modeller. I modell 1 analyseras sambanden utan justering, i modell 2 har en justering gjorts för sociala bakgrundsförhållanden (ålder, skolutbildning, hushållstyp, etnicitet samt

\section{Figur 3b.}

Ekonomi-sociala band modellen och skam- och skamrelaterade känslor i samband med att man handlat med rekvisition, fördelat på kvinnor och män.

\section{SOCIALA BAND}

\section{Tryggare Otryggare}

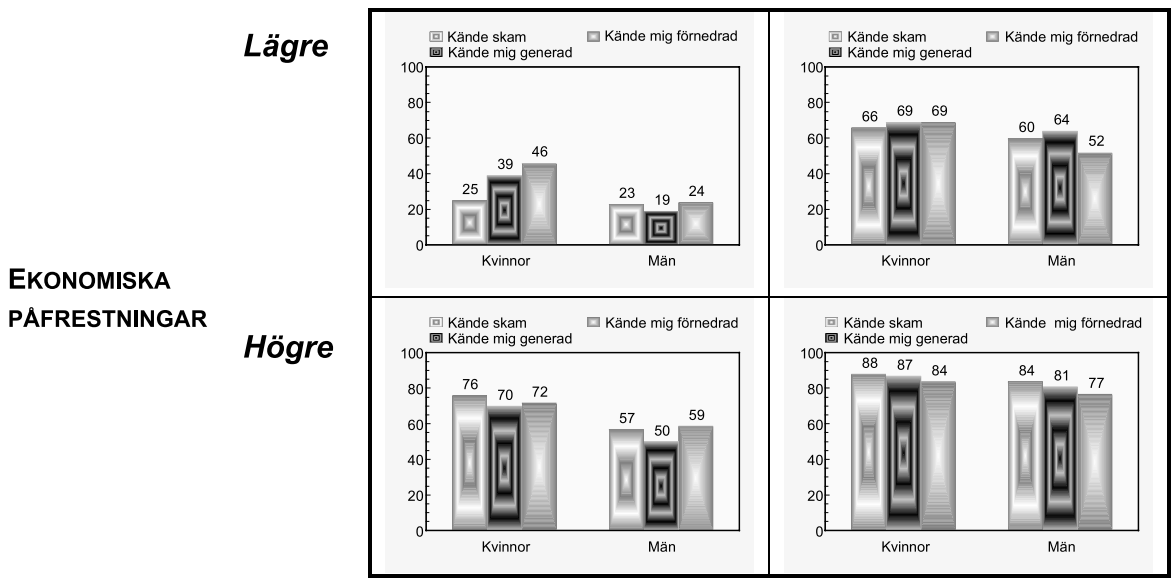

Starrin, Kallander Blomkvist \& Janson: Socialbidragstagande och statusbunden skamkänsla ... 
hur många år under 1990-talet som man ansökt om socialbidrag). I modell 3 har en justering, utöver det som finns i modell 2, även gjorts för faktorn förtroende för socialsekreterare. Det övergripande mönstret är att alla de tre modellerna ger stöd för de grundläggande antagandena i ekonomisociala band modellen. Om vi ser till tabell 3a som redovisar utfallet för kvinnor framgår att oddskvoterna för att känna skam eller skamrelaterade känslor (generad, förnedrad) är mellan 5 och 23 gånger större i gruppen "högre-otryggare» än i gruppen "lägre-tryggare». Med några få undantag förändras inte de relativa skillnaderna mellan grupperna i de olika modellerna för de tre känslorna. För "generad» ökar oddskvoten markant för "högre-otryggare" i modell 2 dvs när det skett en justering för inflytelserna från sociala bakgrundsförhål- landen. I modell 3 sker en liten minskning av alla oddskvoter vilket kan tolkas som att förtroendet för socialsekreteraren har en dämpande effekt på skam- och skamrelaterade känslor även om den dämpande effekten är marginell.

Vi kan också se av tabell 3a att oddskvoterna för gruppen »högre-otryggare« är betydligt högre vad gäller känslan skam än vad de är för "generad" och "förnedrad" vilket indikerar att "skam" har en starkare koppling till ekonomi-sociala band modellen än vad "generad" och "förnedrad" har.

I tabell $3 \mathrm{~b}$ redovisas utfallet för män. Vi kan notera att det sker en ökning i oddskvoterna för grupperna »högre-tryggare» och "högre-otryggare» i modell 2 jämfört med modell 1 för generad och skam medan det för dessa grupper sker en minskning för känslan förnedrad. För »skam» och "gene-

\section{Tabell 3a.}

Skam och skamrelaterade känslor $i$ samband med att man handlat med rekvisition, oddskvot. tre modeller. kvinnor

\begin{tabular}{|c|c|c|c|c|c|c|c|c|c|}
\hline & \multicolumn{3}{|c|}{ Kände skam } & \multicolumn{3}{|c|}{ Kände mig generad } & \multicolumn{3}{|c|}{ Kände mig förnedrad } \\
\hline & Modell & Modell & Modell & Modell & Modell & Modell & Modell & Modell & Modell \\
\hline & 1 & 2 & 3 & 1 & 2 & 3 & 1 & 2 & 3 \\
\hline \multicolumn{10}{|l|}{ Ekonomi-sociala band modellen } \\
\hline $\begin{array}{l}\text { Lägre grad av ek. påfrestn. och } \\
\text { tryggare sociala band }\end{array}$ & I & 1 & । & 1 & । & 1 & 1 & । & I \\
\hline $\begin{array}{l}\text { Lägre grad av ek. påfrestn. och } \\
\text { otryggare sociala band }\end{array}$ & $5.8 * * *$ & $5.0 * * * *$ & $4.6 * * * *$ & $3.5^{* * * * *}$ & $3.9^{* * * *}$ & $3.6 * *$ & $2.6 *$ & 2.3 e.s. & 1.9 e.s. \\
\hline $\begin{array}{l}\text { Högre grad av ek. påfrestn. och } \\
\text { tryggare sociala band }\end{array}$ & $9.3 * * *$ & $7.9 * * * *$ & $7.6 * * * *$ & $3.7 * * * *$ & $3.9 * *$ & $3.9 * *$ & $3.0 * *$ & $2.3^{*}$ & 2.0 e.s. \\
\hline $\begin{array}{l}\text { Högre grad av ek. påfrestn. och } \\
\text { otryggare sociala band }\end{array}$ & $22.7 * * * *$ & 23.1 ***** & $20.1 * * * *$ & $9.9 * * * *$ & $\begin{array}{l}14.0 \\
* * * * *\end{array}$ & $\begin{array}{l}13.1 \\
* * * *\end{array}$ & $6.7 * * *$ & $5.9 * * * *$ & 5.2 ***** \\
\hline
\end{tabular}


radı ökar styrkan i ekonomi-sociala band modellen och för "förnedrad" så minskar den. Vi kan i likhet med vad som är fallet för kvinnor se att oddskvoterna minskar något i modell 3 vilket skulle kunna tolkas som att förtroende för den handläggande socialsekreteraren i någon mån har en dämpande verkan på skam och skamrelaterade känslor.

Värt att notera är att upplevelsen av förnedring har en svagare koppling till ekonomi-sociala band modellen än vad de andra känslorna har.

\section{Diskussion}

Ekonomi-sociala band modellen fogar samman två samhällsvetenskapliga framställningar om skam. Den ekonomiska sidan beaktar den sida som knyter skam och skamrelaterade känslor till bl.a. fattigdom, låg social status och social utsatthet. Den sida som handlar om sociala band förbinder skam och skamrelaterade känslor med kvaliteten i de sociala relationerna. I den här konkreta studien rymmer denna sida även en statusaspekt. Det antagande som formulerades var att (i) kombinationen »högre grad av ekonomisk påfrestning" och "otryggare sociala band" är förenat med omfattande skam- och skamrelaterade känslor och (ii) kombinationen »lägre grad av ekonomisk påfrestning" och "tryggare sociala band" är förenat med ringa skamoch skamrelaterade känslor. Resultatet från undersökningen gav ett starkt stöd för dessa antaganden.

I undersökningen har frågor ställts om skamoch skamrelaterade känslor i anslutning till

\section{Tabell 3b.}

Skam och skamrelaterade känslor $i$ samband med att man handlat med rekvisition, oddskvot, tre modeller, män

\begin{tabular}{|c|c|c|c|c|c|c|c|c|c|}
\hline & \multicolumn{3}{|c|}{ Kände skam } & \multicolumn{3}{|c|}{ Kände mig generad } & \multicolumn{3}{|c|}{ Kände mig förnedrad } \\
\hline & $\begin{array}{c}\text { Modell } \\
\text { I }\end{array}$ & $\begin{array}{c}\text { Modell } \\
2\end{array}$ & $\begin{array}{c}\text { Modell } \\
3\end{array}$ & $\begin{array}{l}\text { Modell } \\
1\end{array}$ & $\begin{array}{l}\text { Modell } \\
2\end{array}$ & $\begin{array}{c}\text { Modell } \\
3\end{array}$ & $\begin{array}{c}\text { Modell } \\
\mathrm{I}\end{array}$ & $\begin{array}{c}\text { Modell } \\
2\end{array}$ & $\begin{array}{c}\text { Modell } \\
3\end{array}$ \\
\hline Ekonomi-sociala band modellen & & & & & & & & & \\
\hline $\begin{array}{l}\text { Lägre grad av ek. påfrestn. och } \\
\text { tryggare sociala band }\end{array}$ & । & I & 1 & I & 1 & I & । & 1 & । \\
\hline $\begin{array}{l}\text { Lägre grad av ek. påfrestn. och } \\
\text { otryggare sociala band }\end{array}$ & $5.0 * *$ & $3.7 *$ & $3.5 *$ & $7.1 * *$ & $4.1 *$ & $3.9 *$ & $3.3^{*}$ & 2.0 e.s. & 1.6 e.s. \\
\hline $\begin{array}{l}\text { Högre grad av ek. påfrestn. och } \\
\text { tryggare sociala band }\end{array}$ & $\begin{array}{l}4.5 \\
* * *\end{array}$ & $5.3 * *$ & $4.6 * *$ & $4.1 * *$ & $6.3 * *$ & $5.6 * *$ & $4.4 * *$ & 3.7 *** & $3.2 *$ \\
\hline $\begin{array}{l}\text { Högre grad av ek. påfrestn. och } \\
\text { otryggare sociala band }\end{array}$ & $\begin{array}{l}17.4 \\
* * * *\end{array}$ & $\begin{array}{c}21 \\
* * * * *\end{array}$ & $\begin{array}{l}20.1 \\
* * * *\end{array}$ & $\begin{array}{l}17.1 \\
* * *\end{array}$ & $\begin{array}{l}23.4 \\
* * * * *\end{array}$ & $\begin{array}{l}21.0 \\
* * * * *\end{array}$ & $\begin{array}{l}10.6 \\
* * *\end{array}$ & $7.6 * * *$ & $6.4 * * * * *$ \\
\hline
\end{tabular}

Starrin, Kallander Blomkvist \& Janson: Socialbidragstagande och statusbunden skamkänsla ... 
två situationer. Den ena rör känslor i samband med att man handlat med rekvisition och den andra rör känslor i samband med besök på socialkontoret för att ansöka om socialbidrag. I båda fallen pekar resultaten på att upplevelsen av skam har en betydligt starkare koppling till ekonomi-sociala band modellen än vad upplevelsen av förnedring har. I vad mån detta har att göra med att förnedring associeras till mer konkreta och specifika händelser än vad skam gör får tills vidare vara en öppen fråga.

I undersökningen har vi beaktat den potentiella inverkan som relationen till den handläggande socialsekreteraren har för utbredningen av skam- och skamrelaterade känslor. Billquist fann i sin studie att ett vänligt och personligt uppträdande från socialsekreterarens sida kan minska klienternas känslor av obehag och skam (Billquist, 1999). Resultaten från vår studie tyder på att en förtroendefull relation enbart marginellt minskar styrkan i ekonomi-sociala band modellens koppling till utbredningen av skam och skamrelaterade känslor. Detta skulle kunna tyda på att en förtroendefull relation till den handläggande personalen endast i begränsad omfattning förmår mildra och dämpa skam- eller skamrelaterade känslor. De grundläggande orsakerna till statusbunden skam torde ligga på ett djupare plan inbäddat i samhällets värderingsstruktur och i de förhållanden som ligger till grund för hur status fördelas i samhället.

\section{Ekonomi-sociala band modellen}

Det försörjningsstöd som socialbidraget utgör knyter an till den ekonomiska sidan av ekonomi-sociala band modellen. Socialbidraget kan förhindra fattigdom i dess klassiska och absoluta mening dvs den fattigdom som hotar den enskildes fysiska överlevnad. Socialbidraget kan däremot inte på något avgörande sätt förhindra uppkomsten av det som brukar benämnas relativ fattigdom dvs den föreställning om fattigdom som tar hänsyn till sociala normer om vad som i ett givet samhälle anses vara en rimlig och skälig levnadsstandard och som också beaktar sociala förväntningar. Den relativa fattigdomen som begrepp har således en betydelsefull social sida som på ett tydligt sätt kopplar det till människans vara i ett givet samhälle och som gör att det kan knytas till känslor av skam och underlägsenhet. Uppfattningen att även den relativa fattigdomen rymmer skamkänslor är inte ny. Den återfinns hos många som ägnat sig åt att studera fattigdom och utsatthet (Gilligan, 1996). I varje läge när utfallet av den sociala jämförelsen blir negativt, vilket är fallet med den relativa fattigdomen, aktualiseras skamkänslan. Men som denna studie visar finns en viktig koppling mellan graden av ekonomisk påfrestning och utbredningen av skamkänslan. Som tagits upp av flera författare spelar ekonomiska förhållanden en viktig roll för social status och social prestige. De får därigenom också betydelse för den egna självkänslan. Utöver detta fyller ekonomiska förhållanden en rad funktioner. De bidrar till att stabilisera och vidmakthålla en etablerad livsstil. De ger möjligheter till att vidmakthålla och utvidga sociala relationer eftersom pengar oftast är en förutsättning för sociala aktiviteter. Dessutom ger ekonomiska resurser 
en känsla av självkontroll och makt över den egna situationen. Pengar ökar således oberoendet (Underlid, 1992).

Vår tolkning är att med ökad ekonomisk påfrestning följer också en ökad emotionell påfrestning som innefattar skam. Den ökande ekonomiska påfrestningen uttrycker också svårigheter att leva upp till ekonomiska och sociala förväntningar. Med ökande svårigheter att leva upp till dessa krav ökar känslan av tillkortakommanden och som skamkänslan är ett uttryck för. Den högt drivna individualismen som kännetecknar moderna samhällen gör det svårt att hantera den här problematiken på något annat sätt än att just inta dominerande föreställningar. Det innebär också att man kommer att tillskriva sig själv och sina (påstådda bristfälliga) förmågor en avgörande betydelse för uppkomsten av den utsatthet man befinner sig $i$.

Ett rimligt antagande är att socialbidragstagares låga status på det personliga planet yttrar sig i en känsla av social underlägsenhet som förstärker en socialt underordnad position. Krafterna bakom allt detta är komplexa och mångfacetterade. Skam är en känsla som kan väckas både när den enskilde ignoreras och när den enskilde är utsatt för alltför hög observans. Detta kan tyckas märkligt. Men den som synas och granskas för sina påstådda tillkortakommanden och ignoreras för sina förtjänster känner skam. Därmed utgör denna typ av granskning och denna typ av ignorans även ett hot mot de sociala banden.

De andra sidan av ekonomi-sociala band modellen har att göra med i vad mån de sociala banden till andra människor är trygga eller otrygga. Föreliggande under- sökning stödjer Scheffs teori om att känslan av skam har att göra med otrygga sociala band (Scheff, 1990). Och det kan antas att den brist på uppskattning och uppmuntran som är förenat med relativ fattigdom gör det svårare att skapa och upprätthålla trygga sociala band. Brist på uppskattning och uppmuntran bidrar därför att förstärka den enskildes utsatta situation. Här finns beröringspunkter med vad som i stressteoretiska termer ibland betecknas mortifikationell stress dvs en stress som uppstår när den enskilde inte åtnjuter uppskattning och uppmuntran utan i stället är utsatt för omgivningens kritiska blickar, förödmjukelser och klander. Vi antar att ju längre ned en individ befinner sig i den sociala hierarkin desto mindre möjligheter har hon att skydda sig från omgivningens förödmjukelser och klander och desto allvarligare blir följderna.

Mycket talar för att socialbidragstagarnas vardag, i likhet med andra lågstatusgruppers vardagsliv, rymmer en speciell dramatik och en med den förenad stress som ibland brukar benämnas dramaturgisk stress. Indikatorerna på sociala band i denna studie fångar till delar denna typ av stress. Dramaturgisk stress skapas när den enskilde känner sig tvingad att upprätthålla en fasad (framträda på ett visst sätt) för att bli accepterad av andra människor och som är oförenlig med dennes rätta känslor och föreställningar om sig själv (Cockerham, 1978). Detta ger upphov till både en kognitiv och emotionell dissonans. Vår allmänna hypotes är att ju längre ned en individ befinner sig i den sociala hierarkin desto mindre möjligheter har hon att skydda sig från den dramaturgiska stressens negativa konsekvenser. 


\section{Problem och svagheter $i$ undersökningen}

Vi skall avslutningsvis peka på några problem och svagheter i undersökningen. Att empiriskt undersöka skam- och skamrelaterade känslor är problematiskt på många sätt. En sida av detta är att skam som flera författare tagit upp, är en emotion som inte strävar efter offentliggörande (Lewis, 1971, Neckel, 1991, Scheff, 1990) eftersom den är ett resultat av en negativ självvärdering som man inte vill meddela andra. Man skäms helt enkelt för att man skäms. Helen Lewis har visat i sin forskning att emotioner $i$ allmänhet och skam $i$ synnerhet tenderar att vara undertryckta, och därmed icke-erkända, i moderna samhällen (Lewis, 1971). Detta är fenomen som måste beaktas när utsatta människor intervjuas om sin situation av personer som befinner sig i en betydligt högre social position. Som Bourdieu (1999) påpekar är intervjuer en social händelse som innefattar ojämlika sociala relationer. Ofta finns en underliggande makt- och statusstruktur i intervjusituationer där den intervjuade befinner sig på en annan statusnivå än den som intervjuar. Därför skall man inte förvånas om den intervjuade censurerar sina berättelser och sina åsikter. Vad som sägs och inte sägs påverkas av denna asymmetri. I vår undersökning kan vi inte utesluta att de intervjuade haft betänkligheter att berätta om händelser som varit pinsamma och väckt känslor av skam och skamrelaterade känslor. Det skulle då innebära att vi i vår undersökning snarare underskattat än överskattat problemet som har att göra med statusbunden skam.
En annan problematisk sida handlar om själva operationaliseringen av skam. I föreliggande studie har vi dels ställt direkta frågor om skam och dels använt vad Retzinger (1991) benämner kodord för skam (generad, förnedrad, mindervärde etc). Dessa frågor har varit kopplade till specifika situationer som handlandet med rekvisition från socialtjänsten och besök vid socialkontoret för att ansöka om bidrag. Tanken har varit att individens föreställningar om socialbidragstagandets sociala status i samhället aktualiseras i dessa båda situationer. Vi betraktar vårt sätt att mäta skam som sonderande och för framtida studier synes det vara viktigt med en utveckling av mätinstrument som avser att mäta situationsbunden skam. Operationaliseringen av "ekonomi-sociala band» modellen får också betraktas som preliminär.

I föreliggande undersökning är bortfallet betydande. Svarsfrekvensen är under 50 procent vilket innebär att man bör vara försiktig med att dra för långtgående slutsatser av värdet av prövningen av ekonomi-sociala band modellen. Man bör dock samtidigt vara klar över att hypotesprövningars värde inte står och faller med svarsfrekvensens storlek.

Slutligen, i denna studie har vi skapat och prövat en modell, ekonomi-sociala band modellen, för att i någon mån bringa klarhet i den skamproblematik som är kopplad till socialbidragstagande. I likhet med mycket av vetenskapligt modellbyggande och modellutprövande är denna modell preliminär både i uppbyggnad och i utprövning. Vår förhoppning är att den kan tjäna som inspiration och vägledning för fortsatt forskning inom området. 


\section{Referenser}

Billquist, Leila (1999) Rummet, mötet och ritualerna - En studie av socialbyrån, klientarbetet och klientskapet. Göteborg. Institutionen för socialt arbete, 1999 (akademisk avhandling).

Bourdieu, Pierrre (1999) „Understanding» i Bourdieu, P m fl. eds,: The Weight of the World - Social Suffering in Contemporary Society. Oxford: Polity Press.

Cockerham, William C (1978) Medical Sociology. New Jersey: Prentice Hall.

Collins, Randall (1990) "Stratification, Emotional Energy and the Transient Emotions» i Kemper, T D ed,: Research Agendas in the Sociology of Emotions. New York: State University of New York Press, Albany.

Cooley, Charles H. (1922) Human Nature and the Social Order. New York: Scribner's.

Gilligan, James (1996) Violence: reflections on our deadliest epidemic. New York: G. P. Putnam's Sons Publishers.

Goffman, Erving (1967) Interaction Ritual. New York: Anchor.

Golding, Peter \& Middleton, Susan (1982) Images of welfare. Oxford: Martin Robertson.

Gunnarsson, Evy (1993) I välfärdsstatens utmarker: Om socialbidrag och försörjning bland ensamstående kvinnor utan barn. Stockholms universitet. Institutionen för socialt arbete. Rapport i socialt arbete, 64 .

Halleröd, Björn (1993) "Åsikter om socialbidragstagare» i Halleröd, B., Marklund, S., Nordlund. A \& Stattin, M., red,: Konsensuell fattigdom - En studie av konsumtion och attityder till konsumtion. Umeå Studies in Sociology, no 104.

Julkunen, Ilse (1992) Ta missnöjet på allvar. Nordiskt Socialt Arbeid, 2:2, 45-55.

Jönsson, Leif R \& Starrin, Bengt (1999) I socialt underläge - En explorativ studie av arbetslösa bidragssökande. Lund: Meddelanden från Socialhögskolan, 4.

Jönsson, Leif R \& Starrin, Bengt (1998) Ett annat liv - En studie av arbetslöshetens konsekvenser bland arbetslösa i Skåne. Lund: Meddelande från Socialhögskolan, 5.

Kaufman, Gershen (1993) The Psychology of Shame - theory and treatment of shame-based syndromes. London: Routledge \& Kegan Paul.

Kemper, Theodore D (1990) Social Relations and Emotions: A Structural Approach i Kemper, T D ed,: Research Agendas in the Sociology of Emotions. New York: State University of New York Press, Albany.

Lehtinen, Ullaliina (1998) Underdog shame - Philosophical essays on women's internalization of inferiority. University of Göteborg (Doctoral dissertation).

Lewis, Helen (1971) Shame and Guilt in Neurosis. New York: International University Press.

Mayer, John \& Timms, Noel (1970) The client speaks - working class impressions of case work. London: Routledge \& Kegan Paul.

Neckel, Sighard (1991) Status und Scham - Zur symbolischen Reproduktion sozialer Ungleichheit. Frankfurt, New York: Campus.

Nilsson, Gerry (1989) Fattigliv. Lund: Meddelande från Socialhögskolan, 1989:1.

Rank, Mark R (1994) A View from the Inside Out: Recipients' Perception of Welfare. Journal of Sociology and Social Welfare, 21:2, 27-47.

Retzinger, Suzanne M (1991) Violent emotions. Shame and Rage in Marital Quarrels. London: Sage Publications.

Scheff, Thomas J (1990) Microsociology. Chicago: Chicago University Press.

Scheff, Thomas J \& Starrin, Bengt (2002) "Skam och sociala band-Om social underordning och utdragna konflikter». I Meuwisse, A \& Swärd, H red,: Perspektiv på sociala problem. Stockholm: Natur \& Kultur.

Sennett, Richard (1999) När karaktären krackelerar. Stockholm: Atlas.

Sennett, Richard \& Cobb, Jonathan (1973) The Hidden Injuries of Class. New York: Vintage.

Solheim, Liv (1995) Sosialhjelp og sjælvrespekt. Ostlandsforskning. Rapport nr 20.

Starrin, Kallander Blomkvist \& Janson: Socialbidragstagande och statusbunden skamkänsla ... 
Starrin, Bengt \& Jönsson, Leif R (2000) »Socialtjänsten och klienterna" i Meeuwisse, A., Sunesson., S. \& Swärd, H., red,: Socialt arbete -En grundbok. Stockholm: Natur och Kultur. Starrin, Bengt (2001) "Skammen, självet och den sociala underordningen" i Aronsson, G \& Karlsson, J Ch., red,: Tillitens ansikten. Lund: Studentlitteratur, 2001.

Starrin, Bengt \& KalanderBlomqvist, Marina (2001) Det är den där skammen... skammen att inte klara sig själv. Karlstads Universitet, Arbetsrapport 2001:4.

Svallfors, Stefan (1996) Välfärdens moraliska ekonomi - Världsopinionen i 90-talets Sverige. Umeå: Borea.

Swärd, Hans (1995) Young and Poor. Young, 3:3, 20-37.

Underlid, Kjell (1992) Arbeidslaus. Oslo: Det Norske Samlaget.

\section{Summary}

\section{Social assistance and status-bound shame Testing the economy-social bonds model}

The aim of the study was to examine shame and shame-related feelings among recipients of social assistance. This has been done with the aid of the economy-social bonds model, which links two scientific presentations of shame. The economic side considers the aspect that associates shame and shame-related feelings with conditions such as poverty, low social status, and social vulnerability. The side that deals with social bonds associates shame and shame-related feelings with the quality of social relations.

The study applies a broad definition of shame, regarding it as a cluster of emotions including several variants, from small everyday embarrassments to more intensive forms such as humiliation and degradation.

The article is based on data from a study of households which applied for social assistance some time in the second half of 1998 and the first half of $1999(n=1,999)$. In addition, data are used from a qualitative study of people receiving social assistance for at least six months ( $n=35$ ).

The results of the study provided strong support for the two hypotheses formulated, namely, (i) the combination whigher degree of economic strain" and "less secure social bonds" is associated with a high degree of shame and shame-related feelings, and (ii) the combination "lower degree of economic strain" and "secure social bonds" is associated with a low degree of shame and shamerelated feelings.

The support provided by social assistance is connected to the economic side of the economy-social bonds model. The article argues that, although social assistance prevents poverty in its classical sense, it cannot in any way prevent the occurrence of relative poverty, that is, the idea of poverty that takes into consideration social norms for what is considered 
a reasonable standard of living in a given society. Relative poverty thus has a significant social side which gives it associations with feelings of shame and inferiority. It is not new knowledge that relative poverty also involves feelings of shame; this has been found by many who have studied poverty and economic strain.

The other side of the economy-social bonds model deals with the extent to which social bonds with other people are secure or not. The present study supports Scheff's (1990) theory that the sense of shame has to do with insecure social bonds. The lack of appreciation and encouragement that is combined with relative poverty makes it more difficult to create and maintain secure social bonds. The lack of appreciation and encouragement therefore further contributes to reinforcing the vulnerable situation of the individual. 